\title{
A thromboprophylaxis jelentősége nem sebészeti fekvőbeteg-osztályokon
}

\author{
Gadó Klára dr. ${ }^{1,2}$ - Kicsi Dóra eh. ${ }^{2}$ \\ Markovics Dorina ${ }^{3}$. Domján Gyula dr. ${ }^{1,4}$ \\ ${ }^{1}$ Semmelweis Egyetem, Egészségtudományi Kar, Egészségtudományi Klinikai Tanszék, Budapest \\ ${ }^{2}$ Szent Rókus Kórház, Budapest \\ ${ }^{3}$ Semmelweis Egyetem, Egészségtudományi Kar, Budapest \\ ${ }^{4}$ Semmelweis Egyetem, Általános Orvostudományi Kar, I. Belgyógyászati Klinika, Budapest
}

\begin{abstract}
A vénás thromboembolia (VTE), melyhez a mélyvénás thrombosist és a tüdőemboliát soroljuk, igen nagy gyakoriságú betegségcsoport. Szintén nagyon jelentős a VTE-nek tulajdonítható mortalitás. A kórházban kezelt betegek körében az egyik leggyakoribb megelőzhető halálok. A valódi gyakoriságot nehéz megítélni, részint azért, mert igen sok a tünetmentes esemény (melyeket a szekciók ritkábbá válásával utólag sem tudunk igazolni), de azért is, mert sok esetben a hazabocsátást követően alakul ki. A kórházban kezelt betegek vénás thromboemboliájának előidézésében számos tényező játszik szerepet. A mütétes és belgyógyászati jellegű osztályokon eltérő az egyes rizikófaktorok jelentősége. Ebben az összefoglalóban elsősorban a belgyógyászati osztályokon kezelt betegek VTE-megelőzésével foglalkozunk. A VTE-prophylaxis alkalmazásának indikációiról, módjáról határozott irányelv rendelkezik. Ennek ellenére világszerte, így hazánkban is megoldatlan probléma, hogy hogyan szerezzünk érvényt ezeknek az irányelveknek. A hatékony prophylacticus lehetőségek ellenére sajnos az eredmények jelentős kívánnivalót hagynak maguk után. A VTE megnöveli a kórházban töltött napok számát, az ismételten szükségessé váló kórházi felvételeket. Ezek, valamint a kialakuló szövődmények a beteg életminőségének romlásához, sok esetben rokkantsághoz vagy halálhoz vezetnek, és nagymértékben megnövelik az egészségügyi kiadásokat. Ezért a VTE-prevenció hatékonyságának javítása kiemelt jelentőségű egészségpolitikai kérdés.
\end{abstract}

Orv Hetil. 2019; 160(17): 654-661.

Kulcsszavak: vénás thromboembolia, mélyvénás thrombosis, tüdőembolia, antifoszfolipidszindróma, thromboprophylaxis

\section{Importance of thromboprophylaxis in hospitalized non-surgical patients}

Venous thromboembolism (including deep vein thrombosis and pulmonary embolism) is a group of diseases with high morbidity. Mortality caused by venous thromboembolism is also highly significant. It is one of the most frequent preventable causes of death in hospital treated patients. It is not easy to assess the real prevalence of the disease because of the frequent symptomless manifestations (as autopsies become less and less frequent, the number of postmortem diagnoses also decreases) and also because the disease often generates after hospital discharge. There are a number of factors contributing to the development of venous thromboembolism in hospital treated patients. The significance of risk factors differs in the case of patients treated in surgical and medical departments. In this review, the thromboprophylaxis of mainly medical inpatients are discussed. Though there are guidelines about indications and methods of venous thromboprophylaxis, yet it is an unsolved problem to enforce them worldwide and also in Hungary. Despite the effective prophylactic methods, results cannot be considered satisfactory. The number of days spent in hospital and also the number of re-admisson are elevated because of venous thromboembolism. Beside this, the complications also lead to the worsening of the quality of life of these patients, moreover, to disability or death. The financial burden of the health system is also significant. Improvement of the efficacy of the prevention of venous thromboembolism is a highly important issue of health policy.

Keywords: venous thromboembolism, deep vein thrombosis, pulmonary embolism, antiphospholipid syndrome, thromboprophylaxis

Gadó K, Kicsi D, Domján Gy. [Importance of thromboprophylaxis in hospitalized non-surgical patients]. Orv Hetil. 2019; 160(17): 654-661.

(Beérkezett: 2018. november 22.; elfogadva: 2018. december 19.) 


\section{Rövidítések}

ACCP $=($ American College of Chest Physicians $)$ Amerikai Mellkasgyógyászati Szakkollégium; BMI = (body mass index $)$ testtömegindex; BRS $=$ (bleeding risk score) vérzéskockázati pontrendszer; $\mathrm{COPD}=($ chronic obstructive pulmonary disease) krónikus obstruktív tüdőbetegség; ENDORSE = (Epidemiologic International Day for the Evaluation of Patients at Risk for Venous Thromboembolism in the Acute Hospital Care Setting) nemzetközi epidemiológiai nap a vénás thrombosis kockázatának felmérésére akut kórházi kezelésben részesülő betegek körében; ENDORSE-2-HUNGARIA = második epidemiológiai nap a vénás thrombosis kockázatának felmérésére akut kórházi kezelésben részesülő betegek körében $\mathrm{Ma}$ gyarországon; IMPROVE = International Medical Prevention Registry on Venous Thromboembolism; LMWH $=$ (low-molecular-weight heparin) kis molekulatömegű heparin; MVT = (deep vein thrombosis) mélyvénás thrombosis; NYHA $=(\mathrm{New}$ York Heart Association) New York-i Szívbetegséggel Foglalkozó Társaság; $\mathrm{PE}=$ (pulmonary embolism) tüdőembolia; PPS $=($ Padua prediction score $)$ padovai modell szerinti előrejelzési pontszám; RAM = (risk assessment model) kockázatfelmérô modell; VTE = (venous thromboembolism) vénás thromboembolia

\section{A VTE előfordulása}

A vénás thromboembolia (VTE) az egyik legjelentősebb morbiditási és mortalitási tényező a kórházban kezelt belgyógyászati betegeket tekintve. Az Amerikai Egyesült Államokban (USA) VTE miatt kórházi kezelést igénylő betegfelvételre a 2007-2009-es időszakban évente 350000 esetben került sor [1]. Szintén USA-adat szerint 2005-ben a 600000 VTE-esemény kétharmada a kórházi kezelés alatt vagy közvetlenül az elbocsátást követően következett be [2]. A kórházban történő halálozás 5-10\%-áért tehető felelőssé a vénás thromboembolia [3]. A fatális kimenetelű tüdőemboliáknak mintegy 75\%-a a nem sebészeti osztályon kezelt betegek köréből kerül ki [4]. A vénás thromboemboliához kapcsolódó, 30 napon belüli halálozás, amennyiben a beteg nem kap kezelést, a mélyvénás thrombosis (MVT) esetében 3\%, míg tüdőemboliát (PE) követően $31 \%$.

Az európai lakosságot tekintve a VTE becsült éves incidenciája 104-183/100 000 fó [5]. Gyakorisága a stroke előfordulásával megegyező. Más adatok szerint az alsó végtagi MVT és a tüdőembolia együttes incidenciája évente 29-78/100 000 fö, míg önmagában az alsó végtagi MVT éves előfordulása 45-117/100 000 fó [6]. A VTE kialakulásában számos tényező játszik szerepet, melyek komplex módon szövődhetnek egymással.

Az egyik rendkívül fontos tényező az életkor, melynek előrehaladtával a VTE előfordulása nő. Nyolcvanéves korban az incidencia 1\%, majdnem ezerszer gyakoribb, mint a 45 évnél fiatalabbaknál [7]. Tekintettel arra, hogy a belgyógyászati osztályokon történő gyógykezelés a leggyakrabban az idősebb korosztályt érinti, ennek az epidemiológiai adatnak az adott kérdés tárgyalása szempontjából is kitüntetett jelentősége van.
Egy másik nagyon gyakori betegségcsoport, amely a VTE fontos, szerzett rizikótényezőihez tartozik, a daganatos megbetegedések. A daganatos betegek fokozott thrombosiskockázata függ a tumor típusától (pancreas-, tüdő-, agy-, petefészek-daganat, myeloproliferativ betegségek), a tumor stádiumától (IV. stádium), valamint az alkalmazott kezeléstől is [8].

A fentiekben kiemelt két tényező mellett számos olyan faktor ismert, amely az akut megbetegedés miatt kórházban kezelt betegek esetében a VTE kialakulásának kockázatát fokozza. Ezek közé tartozik az elhízás, az anamnézisben szereplő VTE, a megelőzően elszenvedett trauma vagy sebészeti beavatkozás, az ismert thrombophilia, az akut myocardialis infarctus vagy stroke, a szívelégtelenség, az alsó végtagi bénulás, a tartós immobilizáció, az akut infekció, a hormonális terápia, centrális vénás katéter alkalmazása, az emelkedett fehérvérsejtvagy thrombocytaszám [9].

A kórházban kezelt betegek körében kialakuló VTE az összes vénás thromboemboliás esemény $20 \%$-árt felelős [10]. A VTE hajlamos az ismétlődésre: a betegek 30\%ánál 10 éven belül számítani kell az ismételt előfordulásra $[11]$.

A VTE előfordulásával kapcsolatban sajnos csak becslések állnak rendelkezésre, aminek okai között említhetjük azt is, hogy nagyon sok a tünetmentes epizód. A tüdőemboliáknak mintegy 30\%-a tünetmentes MVT következtében alakul ki, és a klinikai tünetekkel jelentkező MVT-hez társulóan 40-50\%-os gyakorisággal találhatunk tüdőemboliát [12]. Mivel manapság ritkábban történik boncolás, a tünetmentes epizódok a halál okaként sem mindig kerülnek felismerésre. Egy másik fontos tényező, hogy a kórházi elbocsátást követően, de a kórházi tartózkodáshoz kapcsolódóan bekövetkező VTE valós előfordulásáról sem rendelkezünk pontos adatokkal.

\section{A VTE-prophylaxis jelentősége a kórházban kezelt betegeken}

A kórházban fekvő betegek 42\%-a közepes/nagy thrombosiskockázattal rendelkezik, 10-20\%-uk esetében lehet arra számítani, hogy kezelésük során vagy közvetlenül a hazabocsátást követően VTE alakul ki. A VTE-esemény gyakoriságának csökkentése csak megfelelően alkalmazott thrombosisprophylaxissal érhető el.

A hatékonyan alkalmazott VTE-megelőzés a VTE rizikóját körülbelül 50\%-kal képes csökkenteni. Sajnos a javulás elsősorban a sebészeti osztályokon volt megfigyelhető, ahol valóban, 2000-ig mintegy 70\%-kal sikerült csökkenteni a VTE incidenciáját. Ez az érték a belgyógyászati osztályokon csupán körülbelül 20\% volt [13]. Az American College of Chest Physicians (ACCP) 2016. évi útmutatója gyógyszeres thromboprophylaxis alkalmazását ajánlja a nagy VTE-kockázatú, kórházban kezelt betegeknél.

A napi gyakorlatban jelentős különbség van az elméleti evidenciák és azok betegágy mellett történő alkalmazá- 
sa között. A betegek 30-45\%-a nem kap az ajánlásoknak megfelelő kezelést, 20-25\%-uk viszont szükségtelenül kapja azt, mely alkalmasint felesleges veszélynek teszi ki a beteget. Mindez fokozottan igaz a VTE-prophylaxissal kapcsolatosan. A betegek 51,8\%-a tekinthető fokozott kockázatúnak a VTE szempontjából, közülük csak 50\% részesül az ajánlásoknak megfelelő prophylaxisban. Az ajánlásoknak megfelelő terápia alkalmazásához való adherencia különösen szerény a kórházban kezelt nem sebészeti betegeket illetôen, ahol a nagy VTE-kockázatú betegek prophylaxisa $20 \%$-kal alacsonyabb, mint a sebészeti osztályokon kezelt betegeké [14].

Nem nyugodhatunk bele abba, hogy a belgyógyászati osztályokon kezelt betegeknek a $60 \%$-a nem az elóírásnak megfelelő thromboprophylaxist kapja [15].

\section{A VTE-prophylaxis hazai gyakorlata}

Az ENDORSE-vizsgálat egy nemzetközi keresztmetszeti felmérés volt, melybe hat kontinens 32 országának 358 kórházát vonták be. A Magyarországra vonatkozó eredményeket 2008-ban tették közzé. A vénás thromboembolia kockázatát és a hatásos prophylaxis alkalmazását vizsgálták az akut kórházi betegellátásban [16]. A felmérés hazai adatai meglepő eredményekkel szolgáltak. A sebészeti osztályokon fekvő betegek $58 \%$-a rendelkezett VTE-rizikóval, és közülük $87 \%$ kapott megfelelő prophylaxist. Ez megfelelt a nemzetközi eredményeknek. Ezzel szemben a nem sebészeti osztályokon kezelt betegek 31\%-a volt vénás thrombosis által veszélyeztetett, közülük azonban csak 28\% kapta meg a hatásos prophylaxist. Másképp fogalmazva tehát, hazánkban a hospitalizált és a VTE által veszélyeztetett belgyógyászati betegek $72 \%$-a nem kapta meg a szükséges thromboprophylaxist. Ez az adat sem tért el lényegesen a nemzetközi számoktól. A vizsgálatot két évvel később megismételték (ENDORSE-2-HUNGARIA). Ekkor a sebészeti osztályokon kezelt betegek 84\%-a, míg a belgyógyászati betegek $40 \%$-a részesült az ajánlásoknak megfelelő thromboprophylaxisban [17].

A Magyar Thrombosis és Haemostasis Társaság a $\mathrm{Ma}$ gyar Közlönyben 2010-ben megjelent „A thromboemboliák kockázatának csökkentése és kezelése" címü 4 . magyar antithromboticus irányelvében - amely az Egészségügyi Minisztérium hivatalos irányelve - felhívja a figyelmet a VTE-rizikó felmérésére, és ajánlási szinten elsőként tartalmazza a kórházi belgyógyászati és sebészeti betegek kockázati kérdőívét [18].

\section{A VTE-rizikófaktorok a kórházban kezelt betegeknél az újabb vizsgálatok tükrében}

Több, nagy epidemiológiai vizsgálatot is végeztek az elmúlt időszakban a kórházban kezelt betegek VTE-rizikójának meghatározására [19]. A legfontosabb tényezőket az alábbiakban ismertetjük.

\section{A társbetegségek hatása a VTE kockázatára}

Az immobilitás változatlanul az egyik legfontosabb tényező. Ezen a 3-4 napot meghaladó csökkent mobilitást értjük általában. A közelmúltban lezajlott VTE, valamint az intenzív osztályos kezelés szintén fontos faktorok.

Az aortaaneurysma, a krónikus vesebetegség, különösen a nephrosisszindrómával járó kórforma igazoltan fokozza a thrombosiskockázatot. Az utóbbi esetében a szérumalbuminszint jó prediktora a VTE várható kialakulásának [20].

Az akut megbetegedések közül a stroke, a szívelégtelenség, a heveny szívinfarktus, a légúti infekciók, az akut pancreatitis és az akut légzési elégtelenség sorolható ide. Szintén fokozott a thrombosiskockázata a teljes parenteralis táplálásra szoruló betegeknek, valamint a centrális vénás katéterrel rendelkezőknek.

A gyulladásos kórképek közül ki kell emelni a gyulladásos bélbetegségeket (Crohn-betegség, colitis ulcerosa); a társuló Clostridium difficile-fertőzés további hajlamosító tényezőt jelent.

\section{Gyógyszerhez kapcsolódó VTE-kockázat}

A fogamzásgátló tabletták (elsősorban az újabb generációs készítmények), a menopauzában alkalmazott hormonpótló kezelés, valamint egyes tumorellenes gyógyszerek ismert módon fokozzák a VTE-kockázatot. Az utóbbiak közül ki kell emelni az angiogenezisgátló thalidomidot és bevacizumabot, a ciszplatint, az emlőtumorban alkalmazott hormonkezelést - például tamoxifent és a szupportív kezelésként alkalmazott eritropoetint. A kemoterápia az átlagpopulációhoz képest 2-6-szoros VTE-rizikó-fokozódást okoz.

\section{A VTE-rizikó becslése a kórházban kezelt betegeken}

A hatékony thromboprophylaxis elengedhetetlen feltétele, hogy ismerjük a kórházi felvételre kerülő beteg thrombosiskockázatát.

Sokféle rizikóbecslő modellt ismerünk, azonban egyik modell alkalmazása sem vált egyeduralkodóvá. Az egyszerü és gyors alkalmazhatóság érdekében a betegeket sokan két csoportra osztják: kockázattal nem rendelkező és kockázattal rendelkező csoportra [21]. Az utóbbiak közé azokat a betegeket sorolják, akik legalább egy vagy két kockázati tényezővel rendelkeznek.

Mindazonáltal véleményünk szerint hasznos egy formális kérdőív használata, mert lehetővé teszi, hogy tudatosan végiggondoljuk, számba vegyük a rizikótényezőket. Segít abban is, hogy figyelembe vegyük a többszörös kockázati tényezők egymást fokozó hatását. A vizsgálatok azt igazolják, hogy a formális kérdőívek mellőzése esetén nem javul számottevően az eredmény [22]. Érdemes arra törekedni, hogy egyszerü, gyorsan kitölthető kérdőívet használjunk. Az alábbiakban bemutatunk né- 
hány lehetséges kockázatfelmérő modellt (risk assessment model - RAM). A genfi, az IMPROVE- és a padovai modell a leggyakrabban alkalmazott VTE-RAM.

\section{A padovai modell (Padua prediction score, PPS)}

Ez a modell 11 paramétert vizsgál (1. táblázat). Az egyes paraméterek 1, 2 vagy 3 ponttal értékelhetők. Nagy VTE-rizikónak számít, ha a beteg $\geq 4$ ponttal rendelkezik, ebben az esetben kell thromboprophylaxist alkalmazni $[23,24]$. Az ACCP az irányelvében a padovai modell alkalmazását javasolja [25].

1. táblázat | Padovai rizikóbecslő rendszer (nagy VTE-kockázat: $\geq 4$ )

\begin{tabular}{lc}
\hline Paraméterek & Pont \\
\hline Aktív malignus tumor* & 3 \\
Megelőző VTE & 3 \\
Csökkent mobilitás ${ }^{\dagger}$ & 3 \\
Már ismert thrombophilia ${ }^{\ddagger}$ & 3 \\
A közelmúltban ( $\leq 1$ hónap) trauma és/vagy sebészeti & 2 \\
beavatkozás & \\
Időskor ( $\geq 70$ év) & 1 \\
Szívelégtelenség és/vagy légzési elégtelenség & 1 \\
Akut szívinfarktus és/vagy ischaemiás stroke & 1 \\
Akut infekció és/vagy reumatológiai megbetegedés & 1 \\
Elhízás (BMI $\geq 30$ kg/m²) & 1 \\
Folyamatban lévő hormonális kezelés & 1 \\
\hline
\end{tabular}

*Helyi vagy távoli metasztázis és/vagy fél éven belül kemoterápia vagy radioterápia.

†Ágyhoz kötöttség legalább 3 napig .

‡Antitrombin-, protein-C- vagy -S-defektus, V.-faktor (Leiden)-mutáció, G20210A protrombingén-mutáció, antifoszfolipidszindróma.

$\mathrm{BMI}=$ testtömegindex $; \mathrm{VTE}=$ vénás thromboembolia

\section{A genfi modell (Geneva risk score)}

A genfi modell 19 tényezőt vesz figyelembe, 0-2 pont között értékeli a szempontokat. Három vagy annál több pont esetén a beteget a nagy VTE-rizikójú csoportba sorolja, ami thromboprophylaxis alkalmazását indokolja. A módosított genfi pontrendszer kevesebb szempontot vesz figyelembe, egyszerúbben alkalmazható (2. táblázat) [26-28].

\section{Az IMPROVE-modell}

\section{(International Medical Prevention Registry on Venous Thromboembolism)}

Több mint 15000 beteg adatait tartalmazó nemzetközi regiszter értékelése alapján készült. A kérdőív 7 független VTE-rizikófaktort tartalmaz, melyek mindegyikére
2. táblázat |A genfi kockázatmodell (nagy rizikójú beteg: $\geq 3$ pont)

\begin{tabular}{|c|c|}
\hline Rizikófaktor & Pont \\
\hline Szívelégtelenség & 2 \\
\hline Légzési elégtelenség & 2 \\
\hline Közelmúltban elszenvedett stroke & 2 \\
\hline Közelmúltban elszenvedett szívinfarktus & 2 \\
\hline Akut infekció (beleértve a szepszist is) & 2 \\
\hline Akut reumatológiai betegség & 2 \\
\hline Myeloproliferativ betegség & 2 \\
\hline Malignus tumor & 2 \\
\hline Nephrosisszindróma & 2 \\
\hline Megelőző VTE & 2 \\
\hline Ismert thrombophilia & 2 \\
\hline >3 nap immobilizáció & 1 \\
\hline >6 órát meghaladó utazás a közelmúltban & 1 \\
\hline Életkor $>60$ év & 1 \\
\hline $\mathrm{BMI}>30 \mathrm{~kg} / \mathrm{m}^{2}$ & 1 \\
\hline Krónikus vénás elégtelenség & 1 \\
\hline Terhesség & 1 \\
\hline Hormonkezelés & 1 \\
\hline Dehidráció & 1 \\
\hline$\geq 3$ pont: nagy rizikójú beteg & $55 \%$ \\
\hline Cut-off $\geq 4$ pont: alulbecslés & $30 \%$ \\
\hline Cut-off $\geq 2$ pont: felülbecslés & $72 \%$ \\
\hline $\begin{array}{l}\text { Nem részesülne prevencióban } \\
\text { (alulkezelés) }\end{array}$ & $44 \%$ \\
\hline $\begin{array}{l}\text { Feleslegesen részesülne prevencióban } \\
\text { (túlkezelés) }\end{array}$ & $41 \%$ \\
\hline
\end{tabular}

Módosított genfi pontrendszer

\begin{tabular}{ll}
\hline Rizikótényező & Pont \\
\hline Életkor>65 év & 1 \\
Anamnézisben VTE & 3 \\
Sebészeti beavatkozás az alsó végtagon 1 hónapon belül & 2 \\
Malignus tumor & 2 \\
\hline Tünetek & \\
Féloldali alsó végtagi fájdalom & 3 \\
Vérköpés & 2 \\
\hline Klinikai jelek & 3 \\
Pulzusszám (75-94) & 5 \\
Pulzusszám (>95) & 4 \\
\hline Féloldali alsó végtagi ödéma & \\
\hline Értékelés & \\
Alacsony kockázat: 0-3 & \\
Közepes kockázat: 4-10 & \\
Nagy kockázat: >11 & \\
\hline
\end{tabular}

$\mathrm{BMI}=$ testtömegindex $; \mathrm{VTE}=$ vénás thromboembolia 
1-3 pont adható a VTE-kockázat erőssége alapján. Az összpontszám határozza meg az egyén VTE-kockázatának mértékét $\mathrm{A} \geq 3$ pontszám nagy rizikót jelent, $\mathrm{a} \leq 3$ érték kis kockázatot. A modell negatív prediktív értéke ح99\% (3. táblázat) [28].

Elérhető online kalkulátor is, mellyel gyorsan és egyszerúen meghatározható a VTE-kockázat mértéke (1. ábra) [29].

3. táblázat

Az IMPROVE-modell (International Medical Prevention Registry on Venous Thromboembolism). A $\geq 3$ pontszám nagy rizikót jelent

\begin{tabular}{l}
\hline Az IMPROVE VTE-rizikómodell független tényezői \\
\hline VTE az anamnézisben \\
Ismert thrombophilia \\
Alsó végtagi paresis \\
Daganatos megbetegedés \\
$\geq 7$ nap immobilizáció \\
Intenzív osztályos vagy coronariaőrzóben kezelés \\
Életkor>60 év
\end{tabular}

VTE = vénás thromboembolia

\section{A VTE-thromboprophylaxis sikertelenségének okai (thromboprophylaxis failure)}

A morbiditási és mortalitási mutatók nem csökkennek az elvárható mértékben. Ennek számos oka van. Nemcsak az irányelvek alkalmazásának elégtelensége játszik benne szerepet, hanem az is, hogy összetett problémáról van szó: egy adott beteg esetében sokszor nem lehet mechanikusan alkalmazni az előírásokat, a beteg a hazabocsátását követően is gondos ellenőrzést igényel. A kórházi kezeléshez kapcsolódó VTE-k 50\%-a a hibásan alkalmazott thromboprophylaxisnak tulajdonítható. A throm-

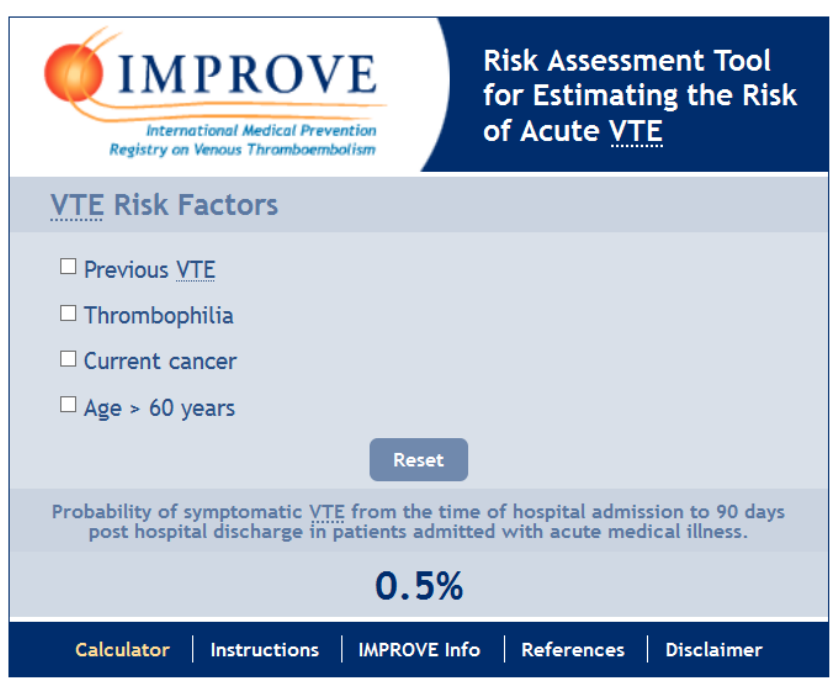

1. ábra

| Online VTE-kockázat-kalkulátor [30]

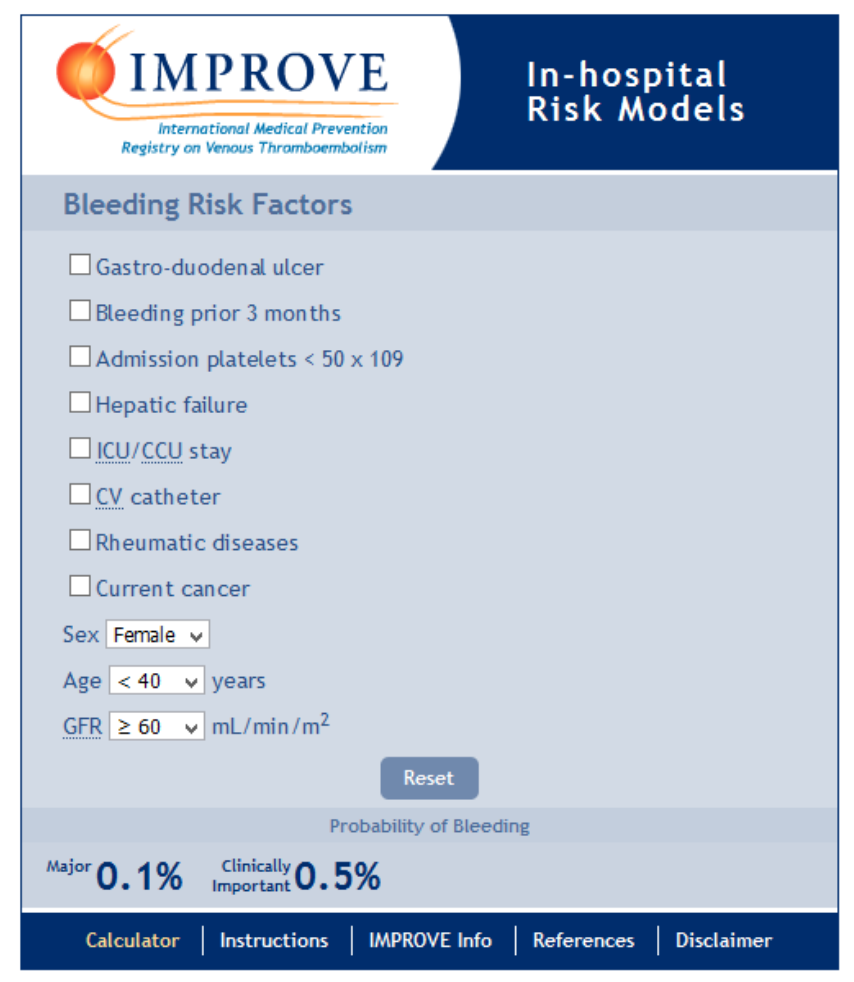

2. ábra | Online vérzéskockázat-kalkulátor [34]

boprophylaxis alkalmazásának elmulasztása mellett egyre nagyobb hangsúlyt kap a sikertelen megelőzés okainak vizsgálata is.

Hogy kellő érvényt szerezzünk a thromboprophylaxis hatékony alkalmazásának, először is tisztában kell lennünk azokkal a tényezőkkel, amelyek ezt hátráltatják [19].

Ezek között tarthatjuk számon

- a VTE-kockázat alábecsülését,

- azt, hogy nincs egységes vélemény azzal kapcsolatosan, hogy egyes tényezők milyen mértékben fokozhatják kórházi kezelés során a VTE kockázatát,

- a belgyógyászati jellegú osztályokon kezelt betegek heterogenitását,

- egyszerű, validált rizikófelmérő módszer hiányát,

- a thromboprophylaxis szubkután alkalmazásának viszszatartó hatását,

- az ezekre a betegekre vonatkozó egységes irányelv hiányát.

A thromboprophylaxis sikertelenségének legfontosabb rizikótényezói közé sorolhatjuk az emelkedett BMI-t, a pozitív egyéni és családi anamnézist, az agysebészeti beavatkozás miatti kórházi kezelést, az intenzív osztályos kezelést, a felvételkor észlehető leukocytosist, a krónikus osztályos kezelést.

A sikertelen prophylaxis csökkentésének számos lehetôsége van. Így a nagyobb dózisban alkalmazott gyógyszeres prevenció, mechanikus thromboprophylaxissal történő kiegészítő kezelés, kiterjesztett ideig alkalmazott gyógyszeres prophylaxis, valamint - egyes vizsgálatok szerint - sztatinok alkalmazása. Egyre inkább előtérbe 
4. táblázat $\mid \mathrm{Az}$ IMPROVE-modell vérzéskockázati pontrendszere (BRS). Nagy vérzéskockázatot jelent $\mathrm{a} \geq 7$ pont

\begin{tabular}{|c|c|}
\hline Rizikótényező & Pont \\
\hline A vesemúködés zavara (GFR: $30-59 \mathrm{ml} / \mathrm{min} / \mathrm{m}^{2}$ ) & 1 \\
\hline Férfinem & 1 \\
\hline Életkor: 40-80 év & 1,5 \\
\hline Malignus tumor jelenléte & 2 \\
\hline Reumatológiai betegség & 2 \\
\hline Centrális vénás katéter & 2 \\
\hline Intenzív osztályon vagy coronariaôrzőn való tartózkodás & 2,5 \\
\hline A vesemúködés zavara $\left(\mathrm{GFR}<30 \mathrm{ml} / \mathrm{min} / \mathrm{m}^{2}\right)$ & 2,5 \\
\hline Májelégtelenség (INR>1,5) & 2,5 \\
\hline Életkor $\geq 85$ év & 3,5 \\
\hline Thrombocytaszám<50 × $10^{9} / \mathrm{L}$ & 4 \\
\hline Vérzés a kórházi felvételt megelőző 3 hónapban & 4 \\
\hline Aktív gastroduodenalis fekély & 4,5 \\
\hline
\end{tabular}

GFR = glomerularis filtrációs ráta; $\mathrm{INR}=$ nemzetközi normalizált ráta

kerül az a felfogás, miszerint nincs mindenki számára egységesen megfelelő VTE-prevenció, egyénre szabott kezelést kell alkalmazni [31].

\section{A vérzési kockázat meghatározása}

A VTE-kialakulás kockázatának nagysága mellett a prophylaxissal kapcsolatos döntéshozatal fontos része az antikoaguláció vérzéses kockázatának meghatározása is. A kétféle kockázat mértékének egybevetése szükséges ahhoz, hogy a kezelés a legkevesebb szövődmény árán legyen megvalósítható.

Sokféle vérzéskockázat-becslő skálát ismerünk. A VTE megelőzéséhez az IMPROVE vérzéskockázati pontrendszere (IMPROVE - BRS) javasolható mint olyan modell, amely nagyszámú beteg alapján külső validáció során is hatékonynak bizonyult (4. táblázat). Klinikailag jelentős vérzéskockázatot (major vérzés + klinikailag jelentős nem major vérzés) jelent a $\geq 7$ pontszám [32-34].

A vérzés kockázatának gyors kiszámításához online kalkulátorok is rendelkezésre állnak [35].

\section{A thromboprophylaxissal elérhető eredmény}

A gyógyszeres thrombosismegelőzés igazoltan hatékony, biztonságos és költségkímélő. A nem sebészeti osztályokon kezelt betegek VTE-kockázatát a hatékonyan alkalmazott thromboprophylaxis a felére csökkenti. Annak ellenére, hogy nincs egységesen elfogadott rizikóbecslő modell, egy könnyen alkalmazható, a vérzéses kockázatokat is tekintetbe vevő kockázatbecslés mindenképpen szükséges ahhoz, hogy kiválasszuk azokat a betegeket, akik nagy thrombosiskockázattal rendelkeznek. A nagy kockázatú betegek thromboprophylaxisa a kórházi tartózkodás alatt, valamint a hazabocsátást követő periódusban az eddigi vizsgálatok alapján egyértelmúen ajánlott.

\section{Hogyan javíthatunk a jelenlegi helyzeten?}

Világszerte látható a törekvés arra vonatkozóan, hogy a VTE előfordulását és az általa okozott egészségromlást, halálozást csökkenteni lehessen. Az egyes szakmai kollégiumok, társaságok megfogalmazzák ajánlásaikat. Ugyanakkor nagyon fontos, hogy helyi szinten is rendelkezzünk protokollokkal.

Az egyes ajánlások időről időre történő újragondolása, újrafogalmazása az újabb tudományos eredmények és a 'real world' vizsgálatok eredményei alapján szintén kívánatos.

A graduális és a posztgraduális képzésben megfelelő hangsúlyt kell helyezni a thromboemboliás megbetegedésekkel kapcsolatos diagnosztikai és terápiás ismeretekre, több oldalról, a kérdés multidiszciplinaritását figyelembe véve kell megközelíteni a kérdést. Rendszeres továbbképzésre van szükség, valamint a helyi gyakorlat közös és rendszeres elemzésére.

A kórházaknak rendelkezniük kell helyi protokollokkal, melyek az általános irányelvekkel összhangban állnak, s ezek alkalmazását rendszeresen ellenőrizni kell. A hazabocsátott beteg további sorsáról visszacsatolt információ szintén javíthatja a kezelőorvos adherenciáját [18].

A hatékony VTE-prophylaxis megvalósításához minden beteg esetében fel kell tenni a kérdést: a VTE-rizikó olyan nagy mértékü, hogy prophylaxis alkalmazása indokolt? Nem áll-e fenn olyan vérzéskockázat, amely ellenjavallja a VTE-prophylaxist? Az adott beteg esetében melyik gyógyszer a leghatékonyabb és a legbiztonságosabb? Milyen mértékü és hosszúságú prophylaxis szükséges ahhoz, hogy a sikertelenséget elkerüljük? Ha erre a négy kérdésre megtaláljuk a megfelelő választ, akkor esélyünk van a VTE morbiditásának és mortalitásának csökkentésére.

Végezetül álljon itt a ma is érvényben lévő vonatkozó hazai ajánlás, az Egészségügyi Minisztérium szakmai irányelve a thromboemboliák kockázatának csökkentésére, melyet a Transzfuziológiai és Hematológiai Szakmai Kollégium és a Magyar Thrombosis és Haemostasis Társaság készített, s melyben függelékként a nem sebészeti osztályokon kezelt betegek thrombosiskockázatának felmérésére alkalmas kockázati kérdőív is található (5. táblázat).

„Közepes és nagy VTE-kockázatú belgyógyászati beteget, ha nincs vérzés vagy annak kifejezett veszélye, antithromboticus (mechanikai és gyógyszeres) prophylaxisban kell részesíteni. A legfontosabb belgyógyászati kockázati tényezők: nephrosisszindróma, szívelégtelenség (NYHA III-IV.), krónikus obstruktív tüdőbetegség (COPD) akut fellángolása, súlyos fertőzések, különösen 
5. táblázat $\mid$ A Transzfuziológiai és Hematológiai Szakmai Kollégium és a Magyar Thrombosis és Haemostasis Társaság által javasolt kockázati kérdőív a nem sebészeti osztályokon kezelt betegek thrombosiskockázatának felmérésére

FÜGGELÉK

Kockázati kérdőív

a gyógyszeres thromboembolia profilaxis szükségességének, eszközeinek, dózisának, illetve ellenjavallatainak megítélésére

\begin{tabular}{|c|c|c|}
\hline \multicolumn{3}{|c|}{ Gyógyszeres VTE profilaxis $N E M-S E B E S E E T I$ osztályokon } \\
\hline Javallatok & $\begin{array}{l}\text { A gyógyszeres } \\
\text { profilaxis }\end{array}$ & Ellenjavallatok \\
\hline 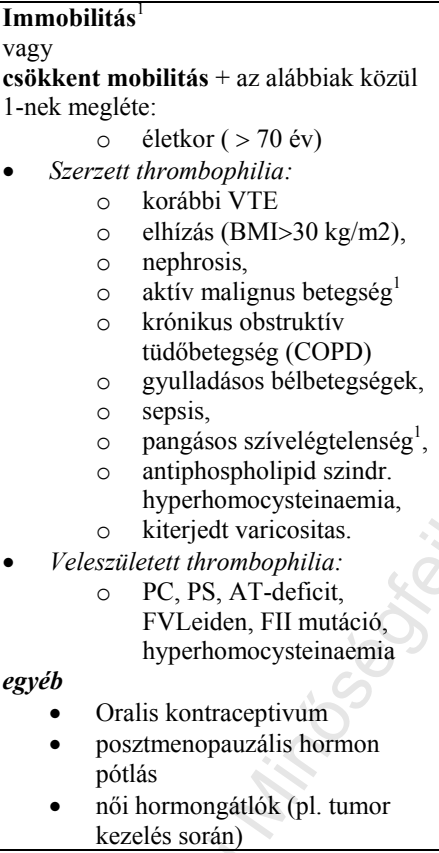 & $\begin{array}{l}\text { Eszköze } \\
\text { LMWH s.c. } \\
\text { Veseelégtelenség } \\
\text { (creatinin clearance < } \\
30 \mathrm{ml} / \text { perc) esetén } \\
\text { UFH, esetleg LMWH } \\
\text { az alkalmazási elöírás } \\
\text { szerinti csökkentett } \\
\text { dózisban! } \\
\text { Időtartama } \\
\text { A kórházi tartózkodás } \\
\text { ideje alatt vagy amíg a } \\
\text { kockázati tényezők } \\
\text { fennállnak }\end{array}$ & 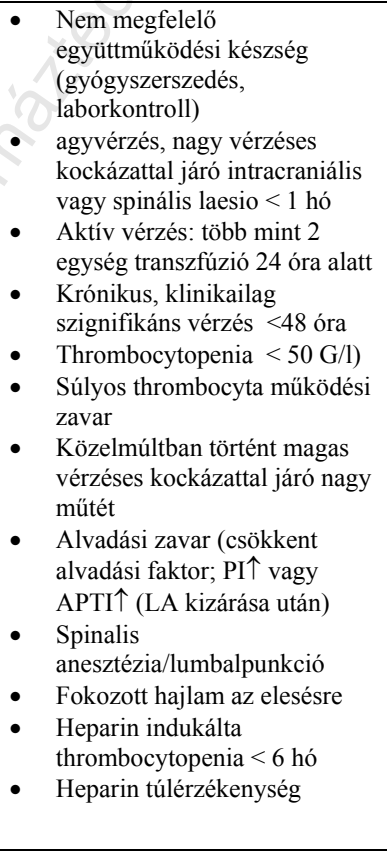 \\
\hline 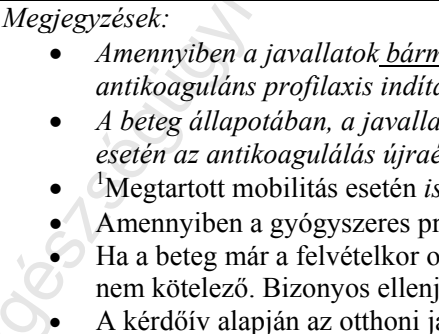 & o!! & $\begin{array}{l}\text { kban bekövetkező változás } \\
\text { is. } \\
\text { kai megelőzés szükséges! } \\
\text { átállítás mérlegelendő, de } \\
\text { a helyzetre vonatkoznak. }\end{array}$ \\
\hline
\end{tabular}

szeptikus állapot, malignus betegségek, myocardialis infarctus, három napnál hosszabb ágynyugalom. A prophylaxis formái: átmeneti - néhány naptól néhány hétig tartó - kockázat során a megelőzésre elsősorban LMWH ajánlott. Az alkalmazott dózis az adott gyógyszer alkalmazási előiratának megfelelő legyen, de esetenként - a kockázat és a vérzésveszély mérlegelése után attól eltérő is lehet. A gyógyszeres megelőzés időtartama általában 6-14 nap, amit a kockázat további fennállása esetén (1. Szerzett rizikófaktorok) nyújtani lehet. Tartósabb (hónapok) megelőzés során is adható LMWH, azonban - ellenőrzési, betegkényelmi, financiális stb. szempontok alapján mérlegelendő a VKA-ra való átállítás. Amennyiben a gyógyszeres ellenjavallt, mechanikai prophylaxis alkalmazandó” [18].
Anyagi támogatás: A szerzők anyagi támogatásban nem részesültek.

Szerzôi munkamegosztás: G. K.: A kézirat összeállítása. G. K., K. D., D. Gy.: A koncepció kidolgozása, a részszakterületek meghatározása, adatgyújtés, javítás, kiegészítés. M. D.: Adatgyưjités. A cikk végleges változatát valamennyi szerző elolvasta és jóváhagyta.

Érdekeltségek: A szerzőknek nincsenek érdekeltségeik.

\section{Irodalom}

[1] Venous thromboembolism in adult hospitalizations - United States, 2007-2009. MMWR Morb Mortal Wkly Rep. 2012; 61: 401-404. 
[2] Heit JA. Venous thromboembolism: disease burden, outcomes and risk factors. J Thromb Haemost. 2005; 3: 1611-1617.

[3] Alikhan R, Peters F, Wilmott R, et al. Fatal pulmonary embolism in hospitalised patients: a necropsy review. J Clin Pathol. 2004; 57: 1254-1257.

[4] Belch JJ, Lowe GD, Ward AG, et al. Prevention of deep vein thrombosis in medical patients by low dose heparin. Scott Med J. 1981; 26: 115-117.

[5] Spencer FA, Emery C, Lessard D, et al. The Worcester Venous Thromboembolism study: a population-based study of the clinical epidemiology of venous thromboembolism. J Gen Intern Med. 2006; 21: 722-727.

[6] Huang W, Goldberg RJ, Anderson FA, et al. Secular trends in occurrence of acute venous thromboembolism: the Worcester VTE study (1985-2009). Am J Med. 2014; 127: 829-839.e5.

[7] Silverstein MD, Heit JA, Mohr DN, et al. Trends in the incidence of deep vein thrombosis and pulmonary embolism: a 25year population-based study. Arch Intern Med. 1998; 158: 585593.

[8] Chee CE, Ashrani AA, Marks RS, et al. Predictors of venous thromboembolism recurrence and bleeding among active cancer patients: a population-based cohort study. Blood 2014; 123 : 3972-3978.

[9] Zakai NA, Callas PW, Repp AB, et al. Venous thrombosis risk assessment in medical inpatients: the medical inpatients and thrombosis (MITH) study. J Thromb Haemost. 2013; 11: 634641 .

[10] Heit JA, Melton LJ 3rd, Lohse CM, et al. Incidence of venous thromboembolism in hospitalized patients vs community residents. Mayo Clin Proc. 2001; 76: 1102-1110.

[11] Verso M, Agnelli G, Ageno W, et al., for the MASTER investigators. Long-term death and recurrence in patients with acute venous thromboembolism: the MASTER registry. Thromb Res. 2012; 130: 369-373.

[12] Marik PE, Plante LA. Venous thromboembolic disease and pregnancy. N Engl J Med. 2008; 359: 2025-2033.

[13] Alikhan R, Peters F, Wilmott R, et al. Fatal pulmonary embolism in hospitalised patients: a necropsy review. J Clin Pathol. 2004; 57: 1254-1257.

[14] Yates M, Reddy M, Machumpurath B, et al. Modification of the National Inpatient Medication Chart improves venous thromboembolism prophylaxis rates in high-risk medical patients. Intern Med J. 2014; 44: 190-194.

[15] Cohen AT, Tapson VF, Bergmann JF, et al. Venous thromboembolism risk and prophylaxis in the acute hospital care setting (ENDORSE study): a multinational cross-sectional study. Lancet 2008; 371: 387-394.

[16] Losonczy H, Tar A. Results of ENDORSE study in Hungary. Multinational, cross-sectional study to assess the prevalence of venous thromboembolism risk and prophylaxis in acute hospital care setting. [Az ENDORSE vizsgálat magyarországi eredményei: az akut kórházi betegek vénásthromboembolia-kockázatának és -profilaxisának nemzetközi, keresztmetszeti felmérésére.] Orv Hetil. 2008; 149: 2069-2076. [Hungarian]

[17] Losonci H, Tar A. Results of ENDORSE-2-HUNGARIA study. Repeated assessment of the prevalence of venous thromboembolism risk and prophylaxis in acute hospital care setting. [Az ENDORSE-2-HUNGARIA vizsgálat eredményei. Az akut kórházi betegek vénásthromboembolia-kockázatának és -profilaxisának ismételt hazai felmérése.] Orv Hetil. 2010; 151: 843852. [Hungarian]

[18] Pfliegler Gy. (ed.) Reduction of the risk of thromboembolism and the treatment. [A thromboemboliák kockázatának csökkentése és kezelése. Az Egészségügyi Minisztérium szakmai irány- elve.] Egészségügyi Minisztérium, Budapest, 2010; p. 58. [Hun garian]

[19] Gerotziafas GT, Papageorgiou L, Salta S, et al. Updated clinical models for VTE prediction in hospitalized medical patients. Thromb Res. 2018; 164(Suppl 1): S62-S69.

[20] Gyamlani G, Molnar MZ, Lu JL, et al. Association of serum albumin level and venous thromboembolic events in a large cohort of patients with nephrotic syndrome. Nephrol Dial Transplant. 2017; 32: 157-164.

[21] Hill J, Treasure T. Reducing the risk of venous thromboembolism in patients admitted to hospital: summary of NICE guidance. BMJ 2010; 340: c95.

[22] Flanders SA, Greene MT, Grant P, et al. Hospital performance for pharmacologic venous thromboembolism prophylaxis and rate of venous thromboembolism: a cohort study. JAMA Intern Med. 2014; 174: 1577-1584.

[23] Barbar S, Noventa F, Rossetto V, et al. A risk assessment model for the identification of hospitalized medical patients at risk for venous thromboembolism: the Padua Prediction Score. J Thromb Haemost. 2010; 8: 2450-2457.

[24] Kahn SR, Lim W, Dunn AS, et al. Prevention of VTE in nonsurgical patients: antithrombotic therapy and prevention of thrombosis, 9th ed.: American College of Chest Physicians EvidenceBased Clinical Practice Guidelines. Chest 2012; 141(2 Suppl): e195S-e226S.

[25] Chopard P, Spirk D, Bounameaux H. Identifying acutely ill medical patients requiring thromboprophylaxis. J Thromb Haemost. 2006; 4: 915-916.

[26] Wicki J, Perneger TV, Junod AF, et al. Assessing clinical probability of pulmonary embolism in the emergency ward: a simple score. Arch Intern Med. 2001; 161: 92-97.

[27] Nendaz M, Spirk D, Kucher N, et al. Multicentre validation of the Geneva Risk Score for hospitalised medical patients at risk of venous thromboembolism. Explicit ASsessment of Thromboembolic RIsk and Prophylaxis for Medical PATients in SwitzErland (ESTIMATE). Thromb Haemost. 2014; 111: 531-538.

[28] Rosenberg D, Eichorn A, Alarcon M, et al. External validation of the risk assessment model of the International Medical Prevention Registry on Venous Thromboembolism (IMPROVE) for medical patients in a tertiary health system. J Am Heart Assoc. 2014; 3: e001152.

[29] VTE Risk Calculator - Web Version. http://www.outcomesumassmed.org/improve/bleeding_risk_score.htm

[30] Northup A, Wilcox S. Thromboprophylaxis failure in the adult medical inpatient. Am J Med Sci. 2017; 354: 107-116.

[31] Decousus H, Tapson VF, Bergmann JF, et al. Factors at admission associated with bleeding risk in medical patients: findings from the IMPROVE investigators. Chest 2011; 139: 69-79.

[32] Mahan CE, Liu Y, Turpie AG, et al. External validation of a risk assessment model for venous thromboembolism in the hospitalised acutely-ill medical patient (VTE-VALOURR). Thromb Haemost. 2014; 112: 692-699.

[33] Zulkifly H, Lip GY, Lane DA. Bleeding risk scores in atrial fibrillation and venous thromboembolism. Am J Cardiol. 2017; 120: $1139-1145$.

[34] Bleeding Risk Score Calculator - Web Version. http://www. outcomes-umassmed.org/improve/bleeding_risk_score.htm

[35] Martín Asenjo M, Martín Guerra JM, Usategui Martín I, et al. Areas of improvement in thromboprophylaxis of hospitalized medical patients. Rev Clin Esp. 2018; 218: 111-113.

(Gadó Klára dr., Budapest, Vas u. 17., 1088 e-mail: gadok@freemail.hu)

A cikk a Creative Commons Attribution 4.0 International License (https://creativecommons.org/licenses/by/4.0/) feltételei szerint publikált Open Access közlemény, melynek szellemében a cikk bármilyen médiumban szabadon felhasználható, megosztható és újraközölhetö, feltéve, hogy az eredeti szerző és a közlés helye, illetve a CC License linkje és az esetlegesen végrehajtott módositások feltüntetésre kerülnek. (SID_1) 